GRASAS Y ACEITES 67 (4)

October-December 2016, e165

ISSN-L: 0017-3495

doi: http://dx.doi.org/10.3989/gya.0562161

\title{
Impact of microwave pre-treatment on the batch anaerobic digestion of two-phase olive mill solid residue: a kinetic approach
}

\author{
B. Rincón ${ }^{\mathrm{a} \otimes}$, M. González de Canales $^{\mathrm{a}}$, A. Martín ${ }^{\mathrm{b}}$ and R. Borja ${ }^{\mathrm{a}}$

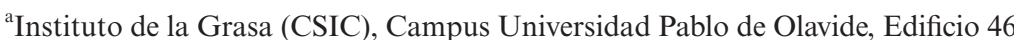 \\ Ctra. de Utrera, km. 1, 41013, Sevilla, Spain \\ ${ }^{\mathrm{b}}$ Departamento de Ingeniería Química y Química Inorgánica, Facultad de Ciencias, Universidad de Córdoba, \\ Campus Universitario de Rabanales, Edificio C-3, Ctra. Madrid-Cádiz, km 396, 14071-Córdoba, Spain \\ ${ }^{\square}$ Corresponding author: brlloren@cica.es
}

Submitted: 11 May 2016; Accepted: 07 July 2016

SUMMARY: The effect of a microwave (MW) pre-treatment on two-phase olive mill solid residue (OMSR) or alperujo with a view to enhancing its anaerobic digestibility was studied. The MW pre-treatment was carried out at a power of $800 \mathrm{~W}$ and at a targeted temperature of $50^{\circ} \mathrm{C}$ using different heating rates and holding times. The following specific energies were applied: $4377 \mathrm{~kJ} \cdot \mathrm{kg} \mathrm{TS}^{-1}$ (MW1), $4830 \mathrm{~kJ} \cdot \mathrm{kg} \mathrm{TS}^{-1}$ (MW2), $7170 \mathrm{~kJ} \cdot \mathrm{kg} \mathrm{TS}^{-1}$ (MW3) and $7660 \mathrm{~kJ} \cdot \mathrm{kg} \mathrm{TS}^{-1}$ (MW4). The maximum methane yield, 395 $\pm 1 \mathrm{~mL} \mathrm{CH}_{4} \cdot \mathrm{g} \mathrm{VS}_{\text {added }}{ }^{-1}$, was obtained for MW4. The effect of the pre-treatment on the kinetics of the process was also studied. The methane production curves generated during the batch tests showed a first exponential stage and a second sigmoidal stage for all the cases studied. In the first stage, the kinetic constant for the pre-treatment MW1 was $54.8 \%$ higher than that obtained for untreated OMSR.

KEYWORDS: Alperujo; Anaerobic digestion; Batch; Kinetics; Microwave

RESUMEN: Impacto del pretratamiento con microondas sobre la digestión anaerobia en régimen discontinuo de residuos sólidos de almazaras de dos fases: un enfoque cinético. El efecto del pretratamiento con microondas (MW) sobre el residuo semisólido procedente de la elaboración del aceite de oliva por el sistema de dos fases o alperujo fue estudiado con el objeto de aumentar su digestibilidad anaerobia. El pretratamiento fue llevado a cabo a una potencia de $800 \mathrm{~W}$ y a una temperatura de $50^{\circ} \mathrm{C}$ empleándose distintas velocidades de calentamiento así como diferentes tiempos de espera para obtener dichas condiciones. Las siguientes energías específicas fueron aplicadas: $4377 \mathrm{~kJ} \cdot \mathrm{kg} \mathrm{TS}^{-1}$ (MW1), $4830 \mathrm{~kJ} \cdot \mathrm{kg} \mathrm{TS}^{-1}$ (MW2), $7170 \mathrm{~kJ} \cdot \mathrm{kg} \mathrm{TS}^{-1}$ (MW3) y $7660 \mathrm{~kJ} \cdot \mathrm{kg} \mathrm{TS}^{-1}$ (MW4). El máximo rendimiento $395 \pm 1 \mathrm{~mL} \mathrm{CH}_{4} \cdot \mathrm{g} \mathrm{SV}_{\text {añadidos }}{ }^{-1}$ se obtuvo para MW4. El efecto del pretratamiento en la cinética del proceso también fue estudiado. Las curvas de producción de metano durante los ensayos mostraron una etapa exponencial y una sigmoidal en todos los casos. En la primera etapa, la constante cinética para MW1 fue $54.8 \%$ mayor que la obtenida para el alperujo sin pretratar.

PALABRAS CLAVE: Alperujo; Cinética; Digestión anaerobia; Microondas; Régimen discontinuo

Citation/Cómo citar este artículo: Rincón B, González de Canales M, Martín A, Borja R. 2016. Impact of microwave pre-treatment on the batch anaerobic digestion of two-phase olive mill solid residue: a kinetic approach. Grasas Aceites 67, e165. http://dx.doi.org/10.3989/gya.0562161

Copyright: (O2016 CSIC. This is an open-access article distributed under the terms of the Creative Commons Attribution (CC-by) Spain 3.0 License. 


\section{INTRODUCTION}

Olive oil production is one of the most important agro-industrial activities in the Mediterranean area (García-Sánchez et al., 2014). 90\% of Spanish olive oil factories currently use the two-phase olive oil milling technology. This technology generates a complex aqueous solid residue from the primary centrifugation step, commonly called olive pomace, alperujo, olive mill solid residue (OMSR) or olive mill solid waste. $800 \mathrm{~kg}$ of OMSR are produced per tonne of olives milled (Rincón et al., 2008a, 2008b, 2009). The average composition of the OMSR is: water $(60-70 \%)$, lignin $(13-15 \%)$, cellulose and hemicellulose $(18-20 \%)$, olive oil retained in the pulp $(2.5-3 \%)$, and mineral solids $(2.5 \%)$ (Rincón et al., 2013a). Therefore, OMSR has a high organic matter concentration leading to an elevated polluting load. The high level of pollution and large volumes of solid residues generated (more than 2 million tonnes per year in Spain) create serious environmental problems, especially when taking into account the 2,000 existing Spanish olive oil factories, most of which are located in the south of Spain (Borja et al., 2006).

Anaerobic digestion (AD) of solid wastes is an efficient, attractive and well-established option for solid waste treatment because of its excellent waste stabilization and high energy recovery (Page et al., 2014). The AD of particulate materials and complex compounds is carried out by anaerobic microorganisms (Rincón et al., 2013b) and it occurs in four major steps: hydrolysis, acidogenesis, acetogenesis and methanogenesis. Hydrolysis is generally the rate-limiting step when bacteria release extracellular enzymes that break down and further solubilize organic particulate matter to be used as substrate in subsequent reactions (Jackowiak et al., 2011). Therefore, to improve digestion efficiency, the most productive approach is to disrupt the chemical bonds in the material to be subjected to hydrolysis. In fact, the structure and composition of lignocellulosic compounds makes its AD especially difficult (Hendriks and Zeeman 2009). In addition, the presence of lignin in this structure acts as a physical barrier that induces a non-productive adsorption of the enzyme. Thus, with a view to disrupting the lignocellulose structure of the wastes in order to increase its anaerobic digestibility, pre-treatment would appear to be not only ideal but also necessary in some cases. The efficiency of a pre-treatment can be evaluated by the generated matter solubilization, the increase in anaerobic biodegradability and its cost.

Pre-treatment by irradiation with microwaves is one of the methods recently reported in the literature for improving the anaerobic biodegradability of different lignocellulosic, complex wastes and biomass (i.e. wheat straw, microalgae biomass, organic fraction of municipal solid waste, food industrial sewage sludge, etc.) (Beszédes et al., 2011; Jackowiak et al., 2011; Li et al., 2012; Passos et al., 2013; Sapci et al., 2013; Shahriari et al., 2012) as well as of primary and secondary waste activated sludges (WAS) (Eskicioglu et al., 2007; Zheng et al., 2009). Microwaves can improve the rupturing of the cell walls and complex compounds, thus enhancing anaerobic hydrolysis in two different ways (Solyom et al., 2011). Firstly, the thermal effect corresponds to degradation caused by temperature increase. The internal heating and evaporation of the intracellular water causes an increase in internal pressure which in turn can cause the cell wall to rupture. Furthermore, in microwave (MW) pre-treatment energy is supplied by an electromagnetic field directly to the material and this leads to rapid heating throughout the material thickness with reduced thermal gradients. Volumetric heating can also reduce processing times and save energy. Secondly, the so-called 'a-thermal' effect must also be considered. This occurs when the alternating electric field of microwaves is capable of forcing the polarized side chains of the cell wall macromolecules to break their hydrogen bonds, and, thus, alter their structure (Eskicioglu et al., 2007; Jackowiak et al., 2011).

Therefore, MW pre-treatment is an alternative method for conventional heating and could potentially yield better results than classical thermal pre-treatment. However, some temperatures could also favor the generation of certain phenolic compounds and furan derivatives which are undesirable as they are inhibitors of anaerobic microorganisms (Taherzadeh and Karmini, 2008). To sum up, operating conditions must be determined for each specific waste so as to optimize microwave pre-treatments.

Based on the existing knowledge about pre-treatments, including the scarce information reported about the pre-treatment of OMSR, the aim of the present study was to evaluate the MW pre-treatment of alperujo using a power of $800 \mathrm{~W}$ and a targeted temperature of $50{ }^{\circ} \mathrm{C}$ on its anaerobic biodegradability through biochemical methane potential tests. The influence of the heating rate, ramp time, holding time at targeted temperature and, therefore, of the specific energy applied were also assessed. The effect of the above-mentioned MW pre-treatment conditions on the kinetic constants of the anaerobic process and ultimate methane yield were evaluated in BMP tests carried out at the mesophilic temperature $\left(35^{\circ} \mathrm{C}\right)$.

\section{MATERIALS AND METHODS}

OMSR was collected from a two-phase olive oil mill, located in the Instituto de la Grasa (CSIC), Seville, Spain. The OMSR was sieved through a $2 \mathrm{~mm}$ mesh to remove olive stone pieces before characterization and being put to use. The main characteristics of OMSR were: $\mathrm{pH}=4.9 \pm 0.2$; total chemical 
oxygen demand, $\mathrm{CODt}=331 \pm 1 \mathrm{~g} \mathrm{O}_{2} \cdot \mathrm{kg}^{-1}$; soluble chemical oxygen demand, $\mathrm{CODs}=143 \pm 3 \mathrm{~g} \mathrm{O}_{2} \cdot \mathrm{kg}^{-1}$; total alkalinity, $\mathrm{TA}=2.5 \pm 0.1 \mathrm{~g} \mathrm{CaCO}_{3} \cdot \mathrm{kg}^{-1}$; total solids, TS $=265 \pm 3 \mathrm{~g} \cdot \mathrm{kg}^{-1}$; volatile solids, VS $=228 \pm 2$ $\mathrm{g} \cdot \mathrm{kg}^{-1} ;$ ammoniacal nitrogen, $\mathrm{AN}=0.3 \pm 0.0 \mathrm{~g}$ ammoniacal $\mathrm{N} \cdot \mathrm{kg}^{-1} ;$ hemicellulose $=11.3 \pm 0.2 \%$; cellulose $=5.2 \pm 0.1 \% ; \quad$ lignin $=19.7 \pm 0.4 \% ; \quad$ and fat $=3.8 \pm 0.3 \%$.

A laboratory Microwave Accelerated Reaction System "Mars 5" (CEM Corporation Matthews, North Carolina) was used to pre-treat the OMSR. Samples were heated to a temperature of $50^{\circ} \mathrm{C}$ using a constant frequency of $2450 \mathrm{MHz}$ and a power of $800 \mathrm{~W}$. To achieve this temperature, ramp times of 2.5 and $10 \mathrm{~min}$ at heating rates of 5 and $20^{\circ} \mathrm{C} \cdot \mathrm{min}^{-1}$, respectively, were used. Once the target temperature was achieved, it was kept for 1,5 and $10 \mathrm{~min}$ in four different combinations, achieving applied specific energies or energy inputs of 4377, 4830, 7170 and $7660 \mathrm{~kJ} \cdot \mathrm{kg} \mathrm{TS}^{-}$. Table 1 shows the different conditions studied: MW1, MW2, MW3 and MW4. To minimize losses, samples were cooled down to room temperature before opening.

The anaerobic experiments were run in $250 \mathrm{~mL}$ reactors. These reactors were continuously stirred at $500 \mathrm{rpm}$ and maintained at $35 \pm 2{ }^{\circ} \mathrm{C}$. An inoculum:substrate ratio of 2 was used (on a VS basis). A trace element solution was also added to each digester, a detailed description of this solution is given elsewhere (Rincón et al., 2010). Two reactors with no added substrate were used as controls. Each experiment was carried out in duplicate.

Biogas was passed through a $3 \mathrm{~N} \mathrm{NaOH}$ solution to capture $\mathrm{CO}_{2}$ on the assumption that the remaining gas was methane. The AD experiments were run until the last day production was lower than $2 \%$ of the accumulated methane produced.

The inoculum used in the BMP assays was obtained from an industrial anaerobic reactor (UASB) treating brewery wastewater at a mesophilic temperature. The characteristics of the anaerobic inoculum used were: $\mathrm{pH}: 7.5$ and VS: $22.2 \mathrm{~g} \cdot \mathrm{L}^{-1}$.

Fat was analyzed by the official EEC method No 2568/91 (EEC Official Diary, L248/1 of 05.09.1991).
Cellulose, lignin and hemicellulose were determined according to the van Soest method (Van Soest et al., 1991). Total chemical oxygen demand (CODt) was determined as described in Rincón et al., (2013a). CODs, AN, TS and VS were determined according to the Standard Methods (APHA, 1998). Specifically, CODs was determined by the method $5220 \mathrm{D}$. TS and VS were determined by the methods $2540 \mathrm{~B}$ and $2540 \mathrm{E}$, respectively. A pH-meter model Crison 20 Basic was used to analyze $\mathrm{pH}$. TA was determined by $\mathrm{pH}$ titration to 4.3 .

\section{RESULTS AND DISCUSSION}

The degree of chemical oxygen demand solubilized was calculated by Eq. 1: where CODs is the soluble chemical oxygen demand measured after each pre-treatment condition tested and CODt, the total initial COD of the OMSR (Carrère et al., 2009):

$$
\text { COD solubilization }(\%)=(\mathrm{CODs} / \mathrm{CODt}) * 100 \quad \text { (Eq. 1) }
$$

COD solubilization values of between $41.1 \%$ and $43.1 \%$ were achieved after the different MW pretreatments tested. Table 2 shows the characteristics of two-phase OMSR after the different MW pretreatments in terms of VS, CODt, CODs and COD solubilization.

MW1 achieved the highest value, i.e. $43.1 \%$. This value was slightly higher than that obtained for thermal pre-treated OMSR at $180{ }^{\circ} \mathrm{C}$ for $180 \mathrm{~min}(42 \%)$ (Rincón et al., 2013a). In this way, and in order to assess the 'a-thermal' MW effects for enhancing the anaerobic digestibility of WAS, a pre-treatment range of $50-96^{\circ} \mathrm{C}$, both using MW and conventional heating $(\mathrm{CH})$ was carried out and reported in the literature. In the mentioned case, WAS samples resulted in similar particulate COD and biopolymer (protein and polysaccharide) solubilization and there was no discernable MW 'a-thermal' effect on the COD solubilization of WAS (Eskicioglu et al., 2007).

In the present study, and within the narrow specific energy range applied $\left(4337-7660 \mathrm{~kJ} \cdot \mathrm{kg} \mathrm{TS}{ }^{-1}\right)$ and low targeted temperature used $\left(50{ }^{\circ} \mathrm{C}\right)$, there

TABLE 1. Operational conditions used in MW pre-treatment of OMSR: MW1, MW2, MW3 and MW4

\begin{tabular}{lcccc}
\hline Parameter (unit) & MW1 & MW2 & MW3 & MW4 \\
\hline Power $(\mathrm{W})$ & 800 & 800 & 800 & 800 \\
Targeted temperature $\left({ }^{\circ} \mathrm{C}\right)$ & 50 & 50 & 50 & 50 \\
Ramp time $(\mathrm{min})$ & 10 & 2.5 & 10 & 2.5 \\
Heating rate $\left({ }^{\circ} \mathrm{C} \cdot \mathrm{min}^{-1}\right)$ & 5 & 20 & 5 & 20 \\
Holding time at targeted temperature (min) & 1 & 1 & 5 & 10 \\
Applied energy per g of OMSR $\left(\mathrm{kJ} \cdot \mathrm{g} \mathrm{OMSR}^{-1}\right)$ & 1.16 & 1.28 & 1.9 & 2.03 \\
Applied energy per g of TS $\left(\mathrm{kJ} \cdot \mathrm{kg} \mathrm{TS}^{-1}\right)$ & 4377 & 4830 & 7170 & 7660 \\
\hline
\end{tabular}


TABLE 2. Characteristics of the untreated OMSR and microwave pre-treated OMSR after the different pre-treatments used: MW1, MW2, MW3 and MW4

\begin{tabular}{lccccc}
\hline Parameter (unit) & Untreated OMSR* & MW1 & MW2 & MW3 & MW4 \\
\hline CODs $\left(\mathrm{g} \cdot \mathrm{kg}^{-1}\right)$ & 143 & 142.65 & 138.14 & 136.05 & 137.7 \\
Solubilization (\%) & & 43.1 & 41.7 & 41.1 & 41.6 \\
Volatile solids $\left(\mathrm{g} \mathrm{VS} \cdot \mathrm{kg}^{-1}\right)$ & 228.00 & 227.89 & 233.03 & 223.94 & 221.02 \\
Methane yield $\left(\mathrm{mL} \mathrm{CH}_{4} \cdot \mathrm{g} \mathrm{VS}_{\text {added }}{ }^{-1}\right)$ & $366 \pm 4$ & $303 \pm 9$ & $337 \pm 7$ & $368 \pm 16$ & $395 \pm 1$ \\
\hline
\end{tabular}

*CODt of the untreated OMSR: $331.1 \mathrm{~g} \cdot \mathrm{kg}^{-1}$. OMSR: olive mill solid residue. MW1 (specific energy: $4377 \mathrm{~kJ} \cdot \mathrm{kg} \mathrm{TS}^{-1}$ ), MW2 (specific energy: $4830 \mathrm{~kJ} \cdot \mathrm{kg} \mathrm{TS}^{-1}$ ), MW3 (specific energy: $7170 \mathrm{~kJ} \cdot \mathrm{kg} \mathrm{TS}^{-1}$ ), and MW4 (specific energy: $7660 \mathrm{~kJ} \cdot \mathrm{kg} \mathrm{TS}^{-1}$ ).

was no significant influence of this parameter on COD solubilization. Passos et al., (2013) found that the main parameter influencing biomass solubilization was the application of high specific energies in the range of $21800-65400 \mathrm{~kJ} \cdot \mathrm{kg} \mathrm{TS}{ }^{-1}$ for MW pretreatment of the microalgae biomass. MW irradiation of the primary sludge was found to increase the ratio of CODs/CODt from $2.5 \%$ to $6-7 \%$ for sludge with 4\% TS concentration when the pre-treatment temperature increased from $35^{\circ} \mathrm{C}$ to $90{ }^{\circ} \mathrm{C}$ (Zheng et al., 2009). In the MW pre-treatment of food industrial waste, solubility increased from $9.7 \%$ to more than $40 \%$ when the MW intensity rose from 0.5 to $5 \mathrm{~W} \cdot \mathrm{g} \mathrm{BOD}_{5}^{-1}$ (Beszédes et al., 2011). In the same way, an increase in the CODs/CODt ratio from $9.4 \%$ to $13.8 \%$ in the MW pre-treatment of switchgrass when the temperature increased from $90^{\circ} \mathrm{C}$ to $180^{\circ} \mathrm{C}$ in order to enhance its anaerobic digestibility has recently been reported (Jackowiak et al., 2011). However, these temperatures were much higher than the $50{ }^{\circ} \mathrm{C}$ used in the present study.

As can be seen in Table 2, the methane yields obtained after 20 days of digestion were $303 \pm 9$, $337 \pm 7,368 \pm 16$, and $395 \pm 1 \mathrm{~mL} \mathrm{CH}_{4} \cdot \mathrm{g} \mathrm{VS}_{\text {added }}{ }^{-1}$ for pre-treated OMSR at MW1, MW2, MW3 and MW4 conditions, respectively, and $366 \pm 4 \mathrm{~mL} \mathrm{CH}_{4} \cdot \mathrm{g}$ $\mathrm{VS}_{\mathrm{added}}{ }^{-1}$ for untreated OMSR. Figure 1 shows the variation in the specific methane yield (B), against time for the tests carried out with untreated OMSR and MW pre-treated OMSR for the different specific energies used (MW1, MW2, MW3 and MW4).

Only MW4 led to a slight increase of $8 \%$ in the methane yield with respect to the value obtained for the untreated substrate. In addition, an increase was observed in the methane yield to increased applied specific energy, and the maximum value $(395 \pm 1 \mathrm{~mL}$ $\mathrm{CH}_{4} / \mathrm{g} \mathrm{VS}_{\text {added }}{ }^{-1}$ ) was obtained for the maximum specific energy tested (MW4).

The highest methane yield obtained in the present study at the MW4 condition was of the same order of magnitude as that obtained in BMP tests of thermal pre-treated OMSR at $120{ }^{\circ} \mathrm{C}$ for 180 minutes (392 $\pm 14 \mathrm{~mL} \mathrm{CH}_{4} \cdot \mathrm{g} \mathrm{VS}_{\text {added }}{ }^{-1}$ ) and $4 \%$ higher than that reached for thermal pre-treated OMSR at $180^{\circ} \mathrm{C}$ for 180 minutes $\left(380 \pm 1 \mathrm{~mL} \mathrm{CH}_{4} \cdot \mathrm{g} \mathrm{VS}_{\text {added }}{ }^{-1}\right)$ (Rincón et al., 2013a).
Some studies reported in the literature show an increase in the methane yield of MW pre-treated wastes as compared with the untreated ones. For instance, pre-treated MW WAS at a targeted temperature of $175^{\circ} \mathrm{C}$ produced $31 \pm 6 \%$ more biogas than the untreated WAS by the $18^{ \pm \text {th }}$ day of the BMP test (Toreci et al., 2011). In this light, Eskicioglu et al. (2007) also reported a $16 \pm 4 \%$ increase in biogas production compared to a control for this same substrate after a MW pre-treatment at a temperature of $96{ }^{\circ} \mathrm{C}$. BMP tests of the sludge from sequencing batch reactors subjected to MW pre-treatment at $85^{\circ} \mathrm{C}$ showed a $16 \%$ increase in methane production as compared to untreated sludge. For other complex substrates, such as industrial food waste, specific biogas increased from 220 to $600 \mathrm{~mL} \cdot \mathrm{g}^{-1}$ when the energy applied in the MW pre-treatment increased from 0.5 to $5 \mathrm{~W} \cdot \mathrm{g} \mathrm{BOD}_{5}^{-1}$ (Beszédes et al., 2011). In BMP tests of microalgae biomass grown in wastewater, the final biogas yield increased from $12 \%$ to $78 \%$ when the substrate was pre-treated with $\mathrm{MW}$ at specific energy at an interval of $21,800-65,400 \mathrm{~kJ} \cdot \mathrm{kg}$ $\mathrm{TS}^{-1}$, higher values than those used in the present study (Passos et al., 2013). In the same way, mesophilic batch AD experiments of the organic fraction of municipal solid waste pre-treated with MW at high temperatures showed a 4-7\% improvement in biogas production over the untreated organic fraction of municipal solid waste (control) when the temperature increased from $115^{\circ} \mathrm{C}$ to $145^{\circ} \mathrm{C}$. However, when this substrate was pre-treated at $175^{\circ} \mathrm{C}$, biogas production decreased due to the formation of refractory compounds inhibiting the digestion (Shahriari et al., 2012).

Similarly to the present study, other researchers found no significant differences in methane yields between untreated and MW pre-treated samples. For example, the MW pre-treatment of switch grass at temperatures in the range of $90{ }^{\circ} \mathrm{C}$ to $180{ }^{\circ} \mathrm{C}$ induced no change in the ultimate volume of methane in BMP assays carried out for 42 days but had a positive effect on the reaction kinetics because the time required to reach $80 \%$ of ultimate methane volume was reduced by 4.5 days at $150{ }^{\circ} \mathrm{C}$ using the MW pre-treatment (Jackowiack et al., 2011). In the same way, the low temperature $\left(50-65^{\circ} \mathrm{C}\right)$ 

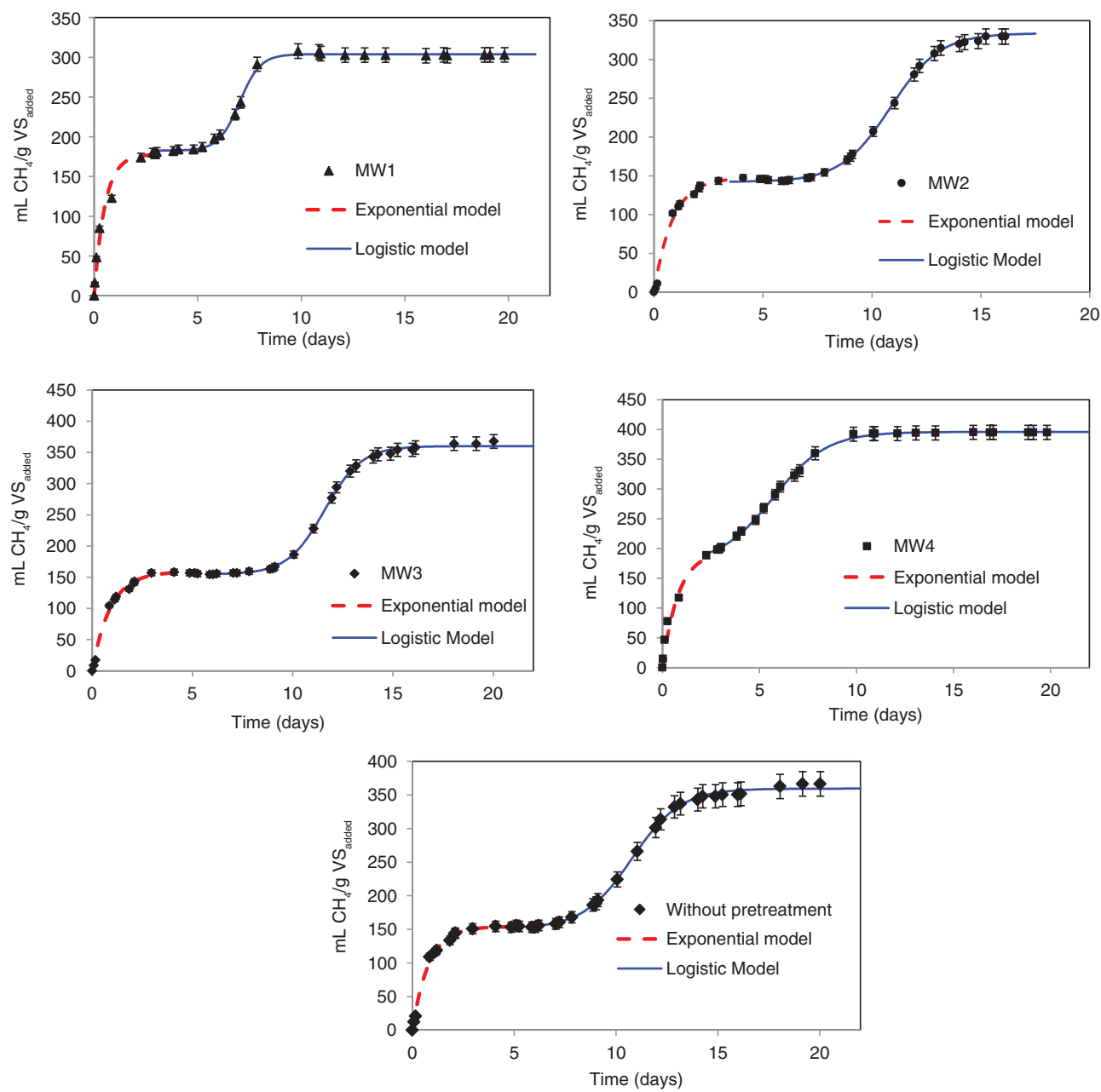

FIGURE 1. Cumulative methane yield, expressed as $\mathrm{mL} \mathrm{CH}_{4} \cdot \mathrm{g} \mathrm{VS}_{\text {added }}{ }^{-1}$, obtained during the BMP tests carried out with untreated OMSR and microwave (MW) pre-treated OMSR at the following operating conditions: MW1 (specific energy: $4377 \mathrm{~kJ} \cdot \mathrm{kg} \mathrm{TS}^{-1}$ ),

MW2 (specific energy: $4830 \mathrm{~kJ} \cdot \mathrm{kg} \mathrm{TS}^{-1}$ ), MW3 (specific energy: $7170 \mathrm{~kJ} \cdot \mathrm{kg} \mathrm{TS}^{-1}$ ), and MW4 (specific energy: $7660 \mathrm{~kJ} \cdot \mathrm{kg} \mathrm{TS}^{-1}$ ).

MW pre-treatment of primary sludge (with $4 \%$ solids concentration) presented no obvious impact on sludge solubilization and ultimate biogas production in BMP tests of this pre-treated substrate carried out for 50 days (Zheng et al., 2009). These temperatures were very similar to those assayed in the present study $\left(50{ }^{\circ} \mathrm{C}\right)$. Finally, BMP assays of grass (Pennisetum hybrid) previously exposed to MW at $260{ }^{\circ} \mathrm{C}$ showed that the maximum production rate and total methane produced decreased by $18 \%$ and $12 \%$, respectively, with respect to the values found for the untreated substrate (Li et al., 2012).

The variation in the methane production with digestion time for untreated OMSR showed two different stages: a first stage of growth followed by a lag period, and a second stage in which the methane production rate increased gradually until the $20^{\text {th }}$ day.

Similar behavior was observed for all the pre-treatments tested: MW1, MW2, MW3 and MW4. Two different models were used to explain this behavior:
A first-order exponential model for the first stage (Li et al., 2012) given by Eq. 2:

$$
B_{1}=B_{\max } \cdot[1-\exp (-k \cdot t)]
$$

where: $B_{1}\left(\mathrm{~mL} \mathrm{CH}_{4} \cdot \mathrm{g} \mathrm{VS}_{\text {added }}{ }^{-1}\right)$ is the cumulative specific methane production, $B_{\max }\left(\mathrm{mL} \mathrm{CH} \mathrm{CH} \mathrm{VS}_{4} \cdot \mathrm{g} \mathrm{ded}^{-1}\right)$ is the ultimate methane production, $k$ is the specific rate constant or apparent kinetic constant $\left(\right.$ days $\left.^{-1}\right)$ and $t$ (days) is the time.

And a sigmoidal model with its three characteristic phases, i.e. lag, exponential increase and final stabilization step was used for the second stage, i.e. between the $5^{\text {th }}$ and $8^{\text {th }}$ days and the last day of the operating period, i.e. the 20th day (Donoso-Bravo et al., 2010; Li et al., 2012):

$B_{2}=B_{0}+P /\left[1+\exp \left(-4 \cdot R_{m} \cdot(t-\lambda) /(P+2)\right)\right]$ 
where: $B_{2}$ is the cumulative methane production during the second stage $\left(\mathrm{mL} \mathrm{CH}_{4} \cdot \mathrm{g} \mathrm{VS}_{\text {added }}{ }^{-1}\right), B_{0}$ is the cumulative methane production at the startup of the second stage $\left(\mathrm{mL} \mathrm{CH}_{4} \cdot \mathrm{g} \mathrm{VS}_{\text {added }}{ }^{-1}\right)$ and should approximately coincide with the value of $B_{\max }$ obtained at the end of the first stage, $P$ is the maximum methane production obtained in the second stage $\left(\mathrm{mL} \mathrm{CH}_{4} \cdot \mathrm{g} \mathrm{VS}_{\text {added }}{ }^{-1}\right), R_{m}$ is the maximum methane production rate $\left(\mathrm{mL} \mathrm{CH} \mathrm{CH}_{4} \cdot \mathrm{g} \mathrm{VS}^{-1} \cdot \mathrm{d}^{-1}\right)$ and $\lambda$ is the lag time (days).

Batch AD experiments of energy crops (i.e. maize, oat, ryegrass and wheat) at mesophilic temperature indicated that the rate of the conversion of these substrates into methane may first reach their maximum rate after several days of digestion and show that the cumulative methane production pattern from these crops followed a sigmoidal, rather than an exponential curve shape (Nielsen and Feilberg, 2012).

$k$ and $B_{\max }$ for this first stage of methane production were calculated by the adjustment by non-linear regression of the pairs of experimental data $B_{1}$, $t$ (Sigmaplot 11.0 software). The goodness of the fit of the experimental data to the model proposed for this first exponential stage is confirmed by the high values of the $R^{2}$ and the low values of the standard error of estimate (S.E.E.).
As can be seen in Table 3, the values of $k$ obtained ranged between from 1.11 00.07 (MW3) to $1.95 \pm 0.16$ days $^{-1}$ (MW1). $k$ was higher for the MW1 pre-treatment at $4377 \mathrm{~kJ} \cdot \mathrm{kg} \mathrm{TS}{ }^{-1}$ of specific energy $\left(k=1.95 \mathrm{~d}^{-1}\right)$ than for the other specific energies studied.

For pre-treatments MW2 and MW3, and for the untreated OMSR, $k$ values were found almost in the same range, between 1.11 and $1.26 \mathrm{~d}^{-1}$. Therefore, the kinetic constant for the MW1 pre-treatment was $64 \%$ and $75 \%$ higher than that obtained for the pre-treated OMSR at MW2 and MW3 conditions respectively, and $55 \%$ higher than for untreated OMSR. The highest value of $k$ (1.95 days $\left.{ }^{-1}\right)$ achieved for the MW1 pre-treated OMSR might be associated with its higher solubilization value $(43.1 \%)$ achieved after pre-treatment, as compared to the other pre-treatment conditions.

In addition, the values of the kinetic constants obtained in the present research work for the MW pre-treated OMSR were higher than those obtained in BMP tests of thermal pre-treated OMSW at 120 ${ }^{\circ} \mathrm{C}$ and $180{ }^{\circ} \mathrm{C}$ for 180 minutes (Rincón et al., 2013a).

During the first stage, $B_{\max }$ for pre-treatment MW4 was higher $\left(196 \mathrm{~mL} \mathrm{CH}_{4} \cdot \mathrm{g} \mathrm{VS}_{\text {added }}{ }^{-1}\right)$ than those obtained for the other MW pre-treatments assayed, whose values ranged between $148 \mathrm{~mL}$

TABLE 3. Kinetic parameters obtained from the exponential and logistic models in the BMP tests of untreated OMSR and microwave pre-treated OMSR under MW1, MW2, MW3 and MW4 conditions

\begin{tabular}{|c|c|c|c|c|c|c|}
\hline \multicolumn{7}{|c|}{ Exponential adjust } \\
\hline & \multicolumn{2}{|c|}{$\boldsymbol{B}_{\max }$} & \multicolumn{2}{|l|}{$\boldsymbol{K}$} & \multirow[b]{2}{*}{$\mathbf{R}^{2}$} & \\
\hline Sample & \multicolumn{2}{|c|}{$\left(\mathrm{mL} \mathrm{CH}_{4} \cdot \mathrm{g} \mathrm{VS}_{\text {added }}{ }^{-1}\right)$} & \multicolumn{2}{|l|}{$\left(\right.$ days $\left.^{-1}\right)$} & & S.E.E. \\
\hline $\begin{array}{l}\text { Untreated } \\
\text { OMSR }\end{array}$ & \multicolumn{2}{|c|}{$154 \pm 2$} & $1.26 \pm 0.07$ & & 0.99 & 3.82 \\
\hline MW1 & \multicolumn{2}{|c|}{$178 \pm 5$} & \multicolumn{2}{|l|}{$1.95 \pm 0.16$} & 0.98 & 10.36 \\
\hline MW2 & \multicolumn{2}{|c|}{$148 \pm 4$} & \multicolumn{2}{|l|}{$1.19 \pm 0.10$} & 0.99 & 6.07 \\
\hline MW3 & \multicolumn{2}{|c|}{$159 \pm 3$} & \multicolumn{2}{|l|}{$1.11 \pm 0.07$} & 0.99 & 4.69 \\
\hline MW4 & \multicolumn{2}{|c|}{$196 \pm 13$} & \multicolumn{2}{|l|}{$1.43 \pm 0.31$} & 0.97 & 14.46 \\
\hline \multicolumn{7}{|c|}{ Logistic adjust } \\
\hline & $B_{0}$ & $P$ & $\boldsymbol{R}_{m}$ & $\lambda$ & & \\
\hline Sample & $\begin{array}{c}\mathrm{mL} \mathrm{CH}_{4} \cdot \mathrm{g} \\
\mathrm{VS}_{\text {added }}{ }^{-1}\end{array}$ & $\begin{array}{c}\mathrm{mL} \mathrm{CH}_{4} \cdot \mathrm{g} \\
\mathrm{VS}_{\text {added }}{ }^{-1} \\
\end{array}$ & $\begin{array}{c}\mathrm{mL} \mathrm{CH} \mathrm{CH}_{4} \cdot \mathrm{g} \\
\mathrm{VS}_{\text {added }}^{-1} \cdot \mathrm{d}^{-1} \\
\end{array}$ & days & $\mathbf{R}^{2}$ & S.E.E. \\
\hline $\begin{array}{l}\text { Untreated } \\
\text { OMSW }\end{array}$ & $151 \pm 2$ & $208 \pm 2$ & 44.0 & $10.8 \pm 0.0$ & 0.99 & 3.5 \\
\hline MW1 & $183 \pm 1$ & $121 \pm 2$ & 61.0 & $7.0 \pm 0.0$ & 0.99 & 2.95 \\
\hline MW2 & $142 \pm 1$ & $192 \pm 2$ & 42.7 & $10.8 \pm 0.0$ & 0.99 & 2.42 \\
\hline MW3 & $155 \pm 1$ & $205 \pm 2$ & 56.2 & $11.6 \pm 0.0$ & 0.99 & 3.04 \\
\hline MW4 & $174 \pm 5$ & $222 \pm 5$ & 40.5 & $5.7 \pm 0.1$ & 0.99 & 2.76 \\
\hline
\end{tabular}

$B_{\max }$ is the ultimate methane production, $k$ is the specific rate constant or apparent kinetic constant, $B_{0}$ is the cumulative methane production at the start-up of the second stage, $P$ is the maximum methane production obtained in the second stage, $R_{m}$ is the maximum methane production rate and $\lambda$ is the lag time. Parameters from the nonlinear regression fit: $\mathrm{R}^{2}$ : coefficient of determination; S.E.E.: standard error of estimate; OMSR: olive mill solid residue. MW1 (specific energy: $4377 \mathrm{~kJ} \cdot \mathrm{kg} \mathrm{TS}^{-1}$ ), MW2 (specific energy: $4830 \mathrm{~kJ} \cdot \mathrm{kg}$ $\mathrm{TS}^{-1}$ ), MW3 (specific energy: $7170 \mathrm{~kJ} \cdot \mathrm{kg} \mathrm{TS}^{-1}$ ), and MW4 (specific energy: $7660 \mathrm{~kJ} \cdot \mathrm{kg} \mathrm{TS}^{-1}$ ). 
$\mathrm{CH}_{4} \cdot \mathrm{g} \mathrm{VS}_{\text {added }}{ }^{-1}$ (MW2) and $178 \mathrm{~mL} \mathrm{CH}_{4} \cdot \mathrm{g} \mathrm{VS}_{\text {added }}{ }^{-1}$ (MW1). These results might indicate a slight increase in easily biodegradable compounds after MW4 pretreatment. However, a high percentage of complex substrates still exists, which diminished the degradation rate.

The logistic model has been previously used for estimating methane production in batch AD experiments of different substrates (Pommier et al., 2007; Donoso-Bravo et al., 2010; Li et al., 2012; Nielsen and Fielberg, 2012). This model assumes the rate of methane production to be proportional to microbial activity (Altas, 2009).

For the logistic model, $P$ obtained in the second stage had the highest value for pretreatment MW4 (222 $\mathrm{mL} \mathrm{CH}_{4} \cdot \mathrm{g} \mathrm{VS}_{\text {added }}{ }^{-1}$ ) followed by the untreated OMSR (208 $\mathrm{mL} \mathrm{CH}_{4} \cdot \mathrm{g} \mathrm{VS}_{\text {added }}{ }^{-1}$ ) and pretreatment MW3 (205 $\mathrm{mL} \mathrm{CH}_{4} \cdot \mathrm{g} \mathrm{VS}_{\text {added }}^{-1}$ ) (Table 3). Moreover, when comparing the values of the $R_{m}$ obtained in the logistic model, the optimum pre-treatment was MW1. Kinetics was the fastest for MW1 with 4377 $\mathrm{kJ} \cdot \mathrm{kg} \mathrm{TS}{ }^{-1}$ of specific energy and with $61.0 \mathrm{~mL}$ $\mathrm{CH}_{4} \cdot \mathrm{g} \mathrm{VS}^{-1} \cdot$ day $^{-1}$ being produced, which is $39 \%$ higher than the value obtained for untreated OMSR and $43 \%, 9 \%$ and $51 \%$ higher than the values found at MW2, MW3 and MW4 conditions, respectively.

Li et al. (2012) also used a logistic function to assess the effect of a MW pre-treatment (at a maximum temperature of $260{ }^{\circ} \mathrm{C}$ and a power of $1,180 \mathrm{~W}$ ) on grass (Pennisetum hybrid) in BMP tests. These authors found that the maximum methane production rate and total methane produced decreased by $18 \%$ and $12 \%$ respectively, compared with untreated raw material.

In the present study, the pre-treatment MW1 with $4377 \mathrm{~kJ} \cdot \mathrm{kg} \mathrm{TS}^{-1}$ of specific energy most likely promotes the release of more easily biodegradable compounds, which allows an increase in the $R_{m}$ and a decrease in the lag period.

The shortest lag phase $(\lambda)$ was obtained for MW4, i.e. 5.7 days, while the longest lag phase was achieved for the untreated OMSR and MW3 pre-treated OMSR (i.e. 10.8 and 11.6 days, respectively). Long lag phases can lead to the generation of different inhibitor compounds that delay the start-up of the second phase in the methane production (Donoso-Bravo et al., 2010). The maximum value of $R_{m}$ achieved in the present work $\left(61.0 \mathrm{~mL} \mathrm{CH}{ }^{\cdot} \cdot \mathrm{g} \mathrm{VS}^{-1} \cdot\right.$ day $\left.^{-1}\right)$ for the MW1 was somewhat lower that that obtained in BMP tests of OMSR previously treated thermally at $180{ }^{\circ} \mathrm{C}$ for $180 \mathrm{~min}\left(76.8 \mathrm{~mL} \mathrm{CH}_{4} \cdot \mathrm{g} \mathrm{VS}^{-1} \cdot \mathrm{day}^{-\mathrm{r}}\right)$ (Rincón et al., 2013a). However, the maximum value of $R_{m}$ reached in the present study was much higher than that obtained in BMP tests of co-digestion mixtures of OMSR and Dunaliella salina with 75\% OMSR-25\% D. salina (48.1 $\mathrm{mL} \mathrm{CH}_{4} \cdot \mathrm{g} \mathrm{VS}^{-1} \cdot \mathrm{day}^{-1}$ ) and $50 \%$ OMSR-50\% D. salina $\left(30.1 \mathrm{~mL} \mathrm{CH}_{4} \cdot \mathrm{g}\right.$ $\mathrm{VS}^{-1} \cdot$ day $^{-1}$ ) (Fernández-Rodríguez et al., 2014).

Taking into account that for pre-treated MW (MW1, MW2 and MW3) the methane yield values obtained were equal to or lower than the methane yield obtained for the untreated OMSR or control; there is no positive energy gain for these three cases. Therefore, for these cases the energy balance would clearly be negative and the MW pre-treatment would not be feasible from a practical point of view.

For the MW4 pre-treatment condition carried out with a specific energy of $7660 \mathrm{~kJ} \cdot \mathrm{kg} \mathrm{TS}^{-1}$, the methane yield (395 $\mathrm{mL} \mathrm{CH}_{4} \cdot \mathrm{g} \mathrm{VS}_{\text {added }}{ }^{-1}$ ) was $8 \%$ higher than that obtained for untreated OMSR (366 $\mathrm{ml} \mathrm{CH} \cdot \mathrm{g} \mathrm{VS}_{\text {added }}{ }^{-1}$ ). This assay corresponded to that performed to $800 \mathrm{~W}$ of power at a targeted temperature of $50{ }^{\circ} \mathrm{C}$, using a heating rate of $20^{\circ} \mathrm{C} \cdot \mathrm{min}^{-1}$ with a ramp time of $2.5 \mathrm{~min}$ and a holding time at the targeted temperature of $10 \mathrm{~min}$. For these MW operating conditions the energy consumed or required for the MW pre-treatment was found to be $9.02 \mathrm{~kJ} \cdot \mathrm{g}$ $\mathrm{VS}^{-1}$. The net energy resulting from the overproduction of methane was calculated by subtracting the methane volume of the untreated sample from that obtained from the MW pre-treated sample. In the present study, this was equal to $+1.04 \mathrm{~kJ} \cdot \mathrm{gVS}^{-1}$.

Therefore, a net balance between the consumed energy in the pre-treatment MW4, $9.02 \mathrm{~kJ} \cdot \mathrm{g} \mathrm{VS}^{-1}$, and the extra energy produced through BMP for the MW4, $1.04 \mathrm{~kJ} \cdot \mathrm{g} \mathrm{VS}^{-1}$, was found to be negative as the extra energy obtained through BMP was not enough to compensate the energy necessary for the pre-treatment.

Jackowiak et al. (2011) also reported a negative energy balance in batch AD experiments of wheat straw pre-treated with MW at much higher values than those used in the present study (maximum power of $1600 \mathrm{~W}$ and a targeted temperature of 260 $\left.{ }^{\circ} \mathrm{C}\right)$. These same authors also reported that to obtain a positive energy balance, a MW device should consume less than $2.65 \mathrm{~kJ} \cdot \mathrm{g} \mathrm{VS}{ }^{-1}$. In the same way, Houtmeyers et al. (2013) reported a negative energy balance during the semi-continuous AD of WAS previously subjected to a MW pre-treatment using a specific energy of $2100 \mathrm{~kJ} \cdot \mathrm{kg}$ sludge ${ }^{-1}$, despite the fact that biogas production was increased by $27 \%$ as compared to untreated WAS.

\section{CONCLUSION}

Microwave pre-treatment of OMSR at specific energies applied in the range of 4377 (MW1)-7660 (MW4) $\mathrm{kJ} \cdot \mathrm{kg} \mathrm{TS}^{-1}$ showed no significant influence on COD solubilization. MW4 led to an $8 \%$ increase in methane yield as compared to the untreated OMSR. Two stages, exponential and sigmoidal, were clearly differentiated in the BMP curves. The highest maximum methane production rate was found for the MW1. During the first stage, the kinetic constant for this pre-treatment was $55 \%$ higher than for untreated OMSR. During the second stage the maximum methane production rate (in the MW1) was $39 \%$ higher than that obtained for untreated OMSR. 


\section{ACKNOWLEDGEMENTS}

The authors wish to express their gratitude to the Ministerio de Ciencia e Innovación (project CTM2011-25762/TECNO) and Junta de Andalucía (project RNM-1970) for providing financial support. Dr. Rincón wishes to thank the Ramón y Cajal Program (RYC-2011-08783 contract) from the Spanish Economy and Competitiveness Ministry for providing financial support.

\section{REFERENCES}

Altas L. 2009. Inhibitory effect of heavy metals on methane-producing anaerobic granular sludge. J. Hazard. Mater. 162, 1551-1556. http://dx.doi.org/10.1016/j. jhazmat.2008.06.048

APHA-AWWA-WPCF. 1998. Standard Methods for the Examination of Water and Wastewater, 20th edn. Washington, DC, USA

Beszédes S, László Z, Szabó G, Hodúr C. 2011. Effects of microwave pretreatments on the anaerobic digestion of food industrial sewage sludge. Environ. Prog. Sustain. Energ. 30, 486-492. http://dx.doi.org/10.1002/ep.10487

Borja R, Raposo F, Rincón, B. 2006. Treatment technologies of liquid and solid wastes from two-phase olive oil mills. Grasas Aceites 57, 32-46. http://dx.doi.org/10.3989/ gya.2006.v57.i1.20

Carrère $\mathrm{H}$, Sialve $\mathrm{B}$, Bernet N. 2009. Improving pig manure conversion into biogas by thermal and thermo-chemical pretreatments. Bioresour. Technol. 100, 3690-3694. http:// dx.doi.org/10.1016/j.biortech.2009.01.015

Donoso-Bravo A, Pérez-Elvira SI, Fernández-Polanco F. 2010. Application of simplified models for anaerobic biodegradability tests. Chem. Eng. J. 160, 607-614. http://dx.doi. org/10.1016/j.cej.2010.03.082

Eskicioglu C, Terzián N, Kennedy KJ, Droste RL, Hamoda M. 2007. Athermal microwave effects for enhancing digestibility of waste activated sludge. Water Res. 41, 2457-2466. http://dx.doi.org/10.1016/j.watres.2007.03.008

Fernández-Rodríguez MJ, Rincón B, Fermoso FG, Jiménez AM, Borja R. 2014. Assessment of two-phase olive mill solid waste and microalgae co-digestion to improve methane production and process kinetics. Bioresour. Technol. 157, 263-269. http://dx.doi.org/10.1016/j. biortech.2014.01.096

García-Sánchez M, Paradiso A, García-Romera I, Aranda E, De Pinto MC. 2014. Bioremediation of dry olive-mill residue removes inhibition of growth induced by this waste in tomato plants. Int. J. Environ. Sci. Technol. 11, 21-32. http://dx.doi.org/10.1007/s13762-012-0170-3

Hendriks ATWM, Zeeman G. 2009. Pretreatments to enhance the digestibility of lignocellulosic biomass. Bioresour: Technol. 100, 10-18. http://dx.doi.org/10.1016/j. biortech.2008.05.027

Houtmeyers S, Appels L, Degrève J, Van Impe J, Dewil R. 2013. Comparing the influence of ultrasonic and microwave pre-treatment on the solubilisation and semi-continuous digestion of waste activated sludge. Proceedings of the Anaerobic Digestion Conference, Paper SPC21, Santiago de Compostela, Spain

Jackowiak D, Bassard D, Pauss A, Ribeiro T. 2011. Optimisation of a microwave pretreatment of wheat straw for methane production. Bioresour. Technol. 102, 6750-6756. http:// dx.doi.org/10.1016/j.biortech.2011.03.107

Li L, Kong X, Yang F, Yuan Z, Sun Y. 2012. Biogas production potential and kinetics of microwave and conventional thermal pretreatment of grass. Appl. Biochem. Biotechnol. 166, 1183-1191. http://dx.doi.org/10.1007/s12010-011-9503-9

Nielsen AM, Feilberg A. 2012. Anaerobic digestion of energy crops in batch. Biosyst. Eng. 112, 248-251. http://dx.doi. org/10.1016/j.biosystemseng.2012.03.008
Page LH, Ni JQ, Herber AJ, Moisier NS, Liu X, Joo HS, Ndegwa PM. Harrison JH. 2014. Characteristics of volatile fatty acids in stored dairy manure before and after anaerobic digestion. Biosyst. Eng. 118, 16-28. http:// dx.doi.org/10.1016/j.biosystemseng.2013.11.004

Passos F, Solé M, García J, Ferrer I. 2013. Biogas production from microalgae grown in wastewater: Effect of microwave pretreatment. Appl. Energ. 108, 168-175. http://dx.doi. org/10.1016/j.apenergy.2013.02.042

Pommier S, Chenu D, Quintard M, Lefebvre X. 2007. A logistic model for the prediction of the influence of water on the solid waste methanization in landfills. Biotechnol. Bioeng. 97, 473-482. http://dx.doi.org/10.1002/bit.21241

Rincón B, Borja R, González JM, Portillo MC, Sáiz-Jiménez C. 2008a. Influence of organic loading rate and hydraulic retention time on the performance, stability and microbial communities of one-stage anaerobic digestion of twophase olive mill solid residue. Biochem. Eng. J. 40, 253-261. http://dx.doi.org/10.1016/j.bej.2007.12.019

Rincón B, Sánchez E, Raposo F, Borja R, Travieso L, Martín MA, Martín A. 2008b. Effect of the organic loading rate on the performance ofanaerobic acidogenic fermentation of two-phase olive mill solid residue. Waste Manage. 28, 870-877. http://dx.doi.org/10.1016/j.wasman.2007.02.030

Rincón B, Borja R, Martín MA, Martín A. 2009. Evaluation of the methanogenic step of a two-stage anaerobic digestion process of acidified olive mill solid residue from a previous hydrolitic-acidogenic step. Waste Manage. 29, 2566-2573. http://dx.doi.org/10.1016/j.wasman.2009.04.009

Rincón B, Banks CJ, Heaven S. 2010. Biochemical Methane potential of winter wheat (Triticumaestivum L.): influence of growth stage and storage practice. Bioresour. Technol. 101， 8179-8184. http://dx.doi.org/10.1016/j. biortech.2010.06.039

Rincón B, Bujalance L, Fermoso FG, Martín A, Borja R. 2013a. Biochemical methane potential of two-phase olive mill solid waste: Influence of thermal pretreatment on the process kinetics. Bioresour. Technol. 140, 249-255. http:// dx.doi.org/10.1016/j.biortech.2013.04.090

Rincón B, Portillo MC, González JM, Borja R. 2013b. Microbial community dynamics in the two-stage anaerobic digestion process of two-phase olive mill residue. Int. J. Environ. Sci. Technol. 10, 635-644. http://dx.doi.org/10.1007/ s13762-013-0290-4

Sapci Z, Morken J, Linjordet R. 2013. An investigation of the enhancement of biogas yields from lignocellulosic material using two pretreatment methods: Microwave irradiation and steam explosion. Bioresources 8, 1976-1985. http:// dx.doi.org/10.15376/biores.8.2.1976-1985

Shahriari H, Warith M, Hamoda M, Kennedy KJ. 2012. Anaerobic digestion of organic fraction of municipal solid waste combining two pretreatment modalities, high temperature microwave and hydrogen peroxide. Waste Manage. 32, 41-52. http://dx.doi.org/10.1016/j.wasman.2011.08.012

Solyom K, Mato RB, Pérez-Elvira SI, Cocero MJ. 2011. The influence of the energy absorbed from microwave pretreatment on biogas production from secondary wastewater sludge. Bioresour. Technol. 102, 10849-10854. http://dx.doi. org/10.1016/j.biortech.2011.09.052

Taherzadeh MJ, Karimi K. 2008. Pretreatment of lignocellulosic wastes to improve ethanol and biogas production: a review. Int. J. Mol. Sci. 99, 1621-1651. http://dx.doi.org/10.3390/ ijms 9091621

Toreci I, Droste RL, Kennedy KJ. 2011. Mesophilic anaerobic digestion with high-temperature microwave pretreatment and importance of inoculum acclimation. Water Environ. Res. 83, 549-559. http://dx.doi.org/10.2175/1061430 10X12780288628651

Van Soest PJ, Robertson JB, Lewis BA. 1991. Methods for dietary fiber neutral detergent fiber and nonstarch polysaccharides in relation to animal nutrition. J. Dairy Sci. 74, 3583-3597. http://dx.doi.org/10.3168/jds.S0022-0302(91)78551-2

Zheng J, Kennedy KJ, Eskicioglu C. 2009. Effect of low temperature microwave pretreatment on characteristics and mesophilic digestion of primary sludge. Environ. Technol. 30, 319-327. http://dx.doi.org/10.1080/09593330902732002 